\title{
De kliniek is de voornaamste plaats om klinische kennis op te doen ${ }^{1}$
}

\author{
J. Stam
}

Als 'klinische kennis' wordt gereduceerd tot klinische ervaring, zou een langdurig verblijf van een leergierige student in een kliniek kunnen volstaan. Hij of zij zou na verloop van tijd allerlei ziektebeelden leren herkennen en behandelen door zijn collega's goed te observeren en te imiteren. Zoiets kan lang goed gaan: onlangs werd een door patiënten en collega's gewaardeerde Italiaanse orthopeed na 20 jaar ontmaskerd als neparts (http:// medischcontact.artsennet.nl; zoeken op "neparts").

Toch zou niemand de geneeskundeopleiding willen terugbrengen tot een praktijkstage. Een arts is een academisch opgeleide expert, met een grote, goed georganiseerde kennis van ziekten en hun behandeling en van hun anatomische, fysiologische en moleculairbiologische achtergronden. Zeker zo belangrijk zijn kennis van de methodologie van het vak en ervaring met wetenschappelijk onderzoek. Een wetenschappelijk gevormde arts kan onderzoeksgegevens naar waarde schatten en is daardoor hopelijk levenslang geïmmuniseerd tegen de reclame van de farmaceutische industrie en de verlokkingen van de kwakzalverij. Het is duidelijk dat dergelijke kennis niet alleen in de kliniek kan worden opgedaan, maar dat daarvoor ook colleges, practica, bibliotheken, computers en onderzoeksstages nodig zijn.

De discussie gaat dus over de dosering van de ingrediënten van de medische opleiding. Met de constatering dat niet-klinische hulpvakken zoals anatomie en medische psychologie van belang zijn voor de geneeskundeopleiding, staat nog niet vast hoe zwaar deze onderwerpen in het curriculum vertegenwoordigd

\section{J. Stam $(\bowtie)$}

Prof. dr. J. Stam is neuroloog.Correspondentieadres:Prof. dr.

J. Stam, Academisch Medisch Centrum/ Universiteit van

Amsterdam, afd. Neurologie, H2-229, Meibergdreef 9, 1105

AZ Amsterdam, j.stam@amc.uva.nl. moeten zijn. Bij de competitie om schaarse onderwijstijd in een steeds voller curriculum zoeken veel niet-klinische vakken een plaats - en de vertegenwoordigers van deze vakken zijn daardoor soms geneigd hun belang te overdrijven. Ook nieuwe stromingen en modes proberen soms een voet tussen de deur van de medische opleiding te krijgen. Zo wordt er de laatste tijd een overdreven nadruk gelegd op niet-medische 'competenties' in plaats van op inhoudelijke deskundigheid. Als bijvoorbeeld de aandacht voor communicatie de klinische vakken zou verdringen, is het resultaat niet een academisch gevormde arts, maar een maatschappelijk werker met een stethoscoop.

De kans dat zoiets gebeurt is niet groot, maar waakzaamheid is geboden. De grotere invloed die managers en onderwijskundigen hebben gekregen ten koste van vakdocenten heeft veel schade aangericht in andere onderwijsvormen, en deze invloed is ook voelbaar in de medische faculteiten. Daarom moet de stelling "klinische kennis kan het beste in de kliniek verkregen worden" met kracht worden verdedigd. De confrontatie met echte patiënten en hun ziekten, onder leiding van een goede klinische docent, ${ }^{1}$ is een intense leerervaring en vormt de kern van de opleiding tot arts. Dit was al bekend bij de Nederlandse pioniers van het klinische onderwijs in de 17 e eeuw en geldt nog onverminderd. ${ }^{2}$

Belangenconflict: geen gemeld.

Financiële ondersteuning: geen gemeld.

\section{Summary}

The amount of learning devoted to clinical teaching in medical schools is under pressure from increased amounts of time devoted to so-called "basic sciences" and recent emphasis on non-medical competencies. Clinical teaching, in direct contact with real

\footnotetext{
${ }^{1}$ Dit artikel verschijnt ook in het Nederlands Tijdschrift voor Geneeskunde. 137 Pro en contra in medisch onderwijs
} 
patients and supervised by experienced clinical teachers, should remain the core of medical education. Competing subjects should be regarded as important, but limited, corollaries. (Stam J. Clinical practice is the most important environment to acquire clinical knowledge. Dutch Journal of Medical Education 2007;26 (3):137-138.)

\section{Literatuur}

Gordon J. ABC of learning and teaching in medicine: one to one teaching and feedback. BMJ 2003;326:543-5.

Gijn J van. Franciscus Sylvius (1614-1672). J Neurol 2001;248:915-6. 